
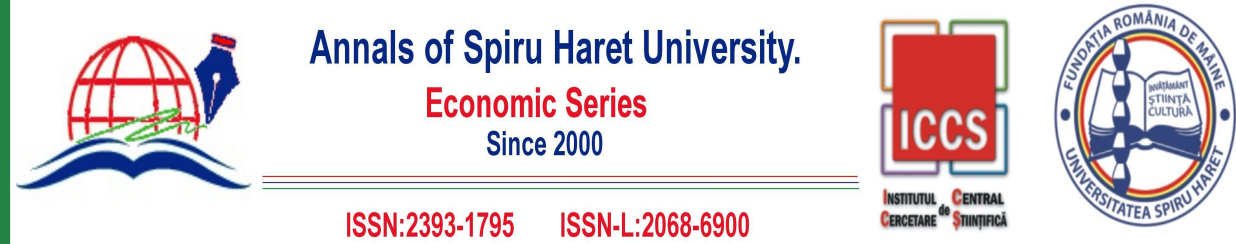

Issue 2/2019

\title{
A RELATIVE ASSESSMENT OF THE CONTRIBUTIONS OF AGRICULTURE, OIL AND NON-OIL TAX REVENUES TO NIGERIA'S ECONOMIC EXPANSION
}

\author{
Cordelia Onyinyechi OMODERO ${ }^{1}$ \\ ${ }^{1}$ Department of Accounting, College of Management Sciences, \\ Michael Okpara University of Agriculture, Umudike, Umuahia, Abia \\ State, Nigeria, Email: cordeliaomodero@yahoo.com
}

How to cite: OMODERO, C. O. (2019). "A Relative Assessment of the Contributions of Agriculture, Oil and Non-Oil Tax Revenues to Nigeria's Economic Expansion." Annals of Spiru Haret University. Economic Series, 19(2), 139-151, doi: https://doi.org/10.26458/1927

\begin{abstract}
The decline in oil prices globally has led to diversification of economy in most oil enriched countries. In Nigeria, more attention is given to agriculture and non-tax revenue sources to ensure that the country overcomes a monoeconomy syndrome which has affected the nation in the past. This study assesses the contributions of agriculture, oil and non-oil tax revenue to economic expansion in Nigeria using data that cover a period from 1981 to 2017. The regression results indicate that oil revenue has a significant negative impact on economic growth which is represented by gross domestic product. On the contrary, the study finds evidence that agriculture and non-oil tax revenue have a robust significant and positive influence on economic growth. Therefore, the study suggests that tax administration in Nigeria should be more business-growth conscious and that agriculture should be given a boost by creating an enabling environment that could attract foreign direct investments in the agricultural sector. The study also recommends that oil revenues should be utilized for reinvestments into other sectors of the economy.
\end{abstract}

Keywords: oil revenue; non-oil tax revenue; agriculture; economic growth; Nigeria. 


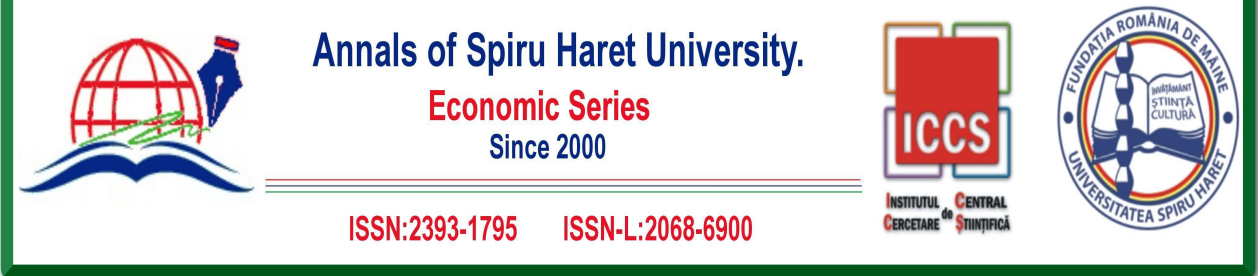

Issue 2/2019

JEL Classifications: H27, H24, H25, N5, O4

\section{Introduction}

The existence of crude oil has been misconstrued as the key element powering the economic growth of Nigeria and yet it does not affect other areas of the economy such as job creation and poverty reduction [Adesola et al., 2014]. The rising growth of Nigeria's GDP is a sham since job opportunities and poverty alleviation have not been realized, rather poverty is at its climax and all economic sectors in the country are in a deplorable stage. Even though there is regular flow of oil revenue, Nigeria still encounters slow pace of economic growth and development [Abubakar, 2011]. The decline in oil prices witnessed in the recent times gave room for policy makers and the government to crave for economy diversification which finds non-oil tax revenue and agriculture as major areas that could offer immediate solution to Nigeria's economic problems. Non-oil tax revenue comprises education tax (EDT), custom and excise duties (CED), value added tax (VAT), companies' income tax (CIT), import duties and grants [Ihendinihu et al., 2014]. Agriculture in Nigeria includes crop production, fishing, forestry and livestock farming.

In the recent times, attention has been drawn to these areas mentioned above in order to reduce the over reliance on oil revenue and to keep the economy going without hitches. Though efforts are made by the relevant authorities to improve the agricultural sector, but yet the sector requires more inputs to be able to operate at full capacity in order to supply sufficient food for the citizens at a reduced and affordable cost [Omodero \& Amah, 2018]. Despite the emphasis on non-oil tax revenue by the government, agriculture is seen as a potential tool for poverty eradication and economic sustenance in Nigeria. Therefore, this study investigates the effect of oil revenue, non-oil tax revenue and agriculture on economic expansion in Nigeria following the emphasis on tax revenues and agriculture presently.

\subsection{Research Hypotheses}

This study is guided by the following null hypotheses.

Ho1: Oil revenue does not have significant influence on economic expansion in Nigeria.

Ho2: Non-oil tax revenue does not significantly affect economic growth in Nigeria. 

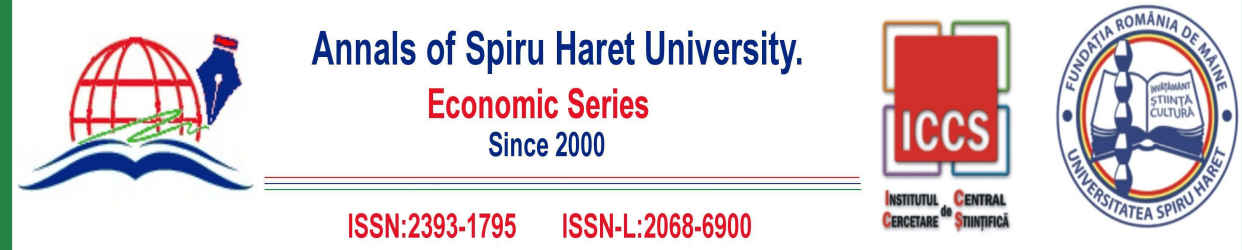

Issue 2/2019

Ho3: Agriculture does not have significant impact on economic growth in Nigeria.

\section{Literature Review}

\subsection{Conceptual Framework}

Below is a model showing the interrelationship and connectivity of the explanatory variables and the response variable used in this study.

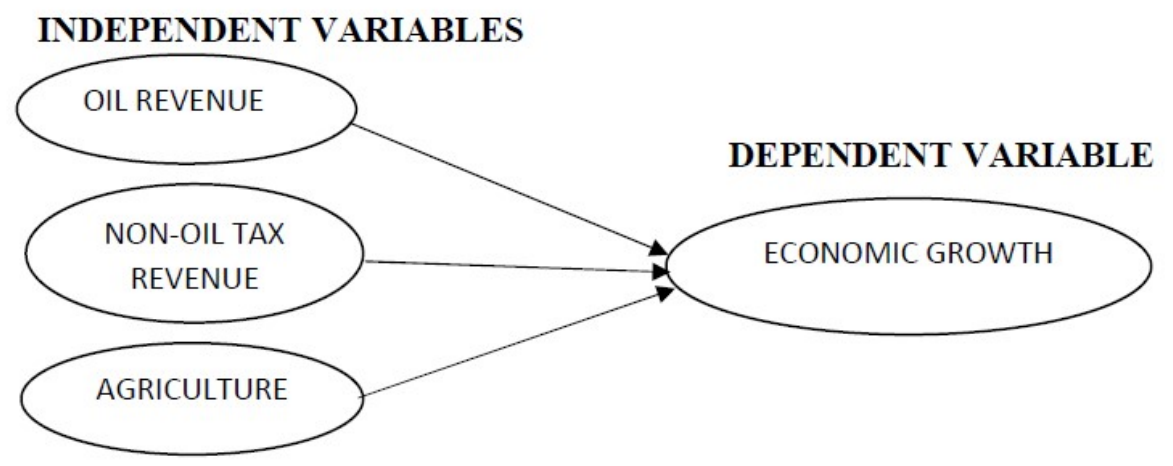

Fig. 1. Conceptual framework of the study Source: Author's Desk Research, 2019.

\subsubsection{The Concept of Oil Revenue and Economic Growth}

Oil revenue refers to the earnings from the sales and export of crude oil and petroleum which are primarily meant for economic expansion in a country. However, in Nigeria the situation is not as viewed by scholars. The oil revenue is under the control of leaders who lack feelings for the citizens and have continued to misuse and embezzle the resources thereby leaving the general public in abject poverty. Hammond (2011) submits that emerging countries enriched with natural resources, especially oil, often do not attain economic growth and its sustainability due to corruption, mismanagement of resources and lack of good governance, which generally affect the standard of living of the entire populace of those countries, thus leading to lack of proper provision of public goods and services. Akinlo (2012) opines that oil sector does not really have positive influence on other sectors in the 


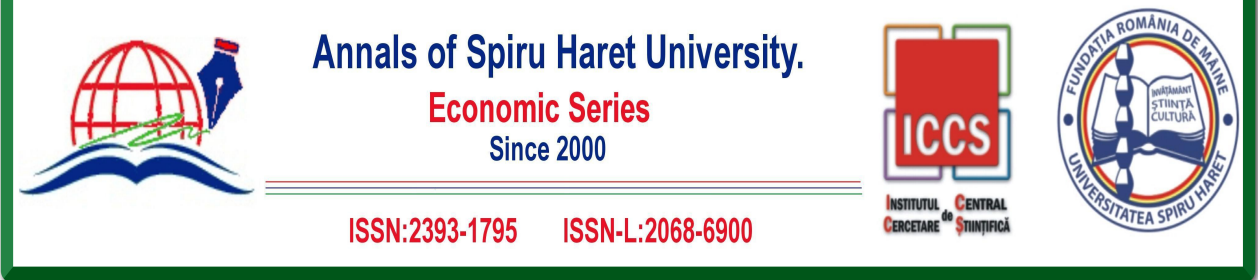

Issue 2/2019

economy. The high revenues from the oil sector deny other sectors attention from the government and, as a result, the economic expansion is affected [Owolabi \& Ajayi, 2013]. Oil revenue is an important component of economic growth which most nations enriched with oil resources go on to exploit the opportunity by investing its revenues into other sectors of the economy for proper economic expansion [Abubakar et al., 2016].

\subsubsection{The Concept of Non-Oil Tax Revenue and Economic Growth}

Non-oil tax revenue in this study is synonymous with tax revenue or taxation. Non-oil tax revenues are not associated with oil but include: education tax (EDT), custom and excise duties (CED), value added tax (VAT), companies income tax (CIT), import duties and grants [Ihendinihu et al., 2014]. Taxation is a compulsory levy imposed by the government on individuals and companies for the various legitimate functions of the state [Popoola et al.]. On the other hand, Ogundele (1999) defines taxation as a mechanism by which communities or groups of persons are made to contribute in a certain substantial and established technique that helps to carry on public services and administrations which are of some benefits to the citizens of a country. The definition is consistent with the description of Soyode and Kajola (2006) who defined tax as an obligatory payment made by citizens to the relevant authority for the purposes of public service delivery by the government. Nightingale (1997) defined tax as an unavoidable levy enforced by the government. These scholars came to a conclusion that, it is likely for tax payers not to receive anything commensurate with their contributions but that they have the advantage of living in a moderately safe, educated and healthy society [Ayuba, 2014]. However, the infrastructures intended for tax payers to really appreciate are all in an improper form [Fafunwa, 2005], the health care system is a huge cause for concern [Lambo, 2005], while the educational system is in total disorder [Obaji, 2005]. Therefore, Sanni (2007) and Okafor (2012) encourage the use of tax revenue as a tool for social engineering, which helps to stimulate sectoral and general economic growth.

\subsubsection{The Concept of Agriculture and Economic Growth}

Agriculture is a panacea and bedrock for economic growth, development and poverty extinction in the emerging countries [Kamil et al., 2017]. Agriculture is the oldest means of sustenance for both industrialized and developing economies. Agriculture supports economic growth of a nation through provision of food, 142 


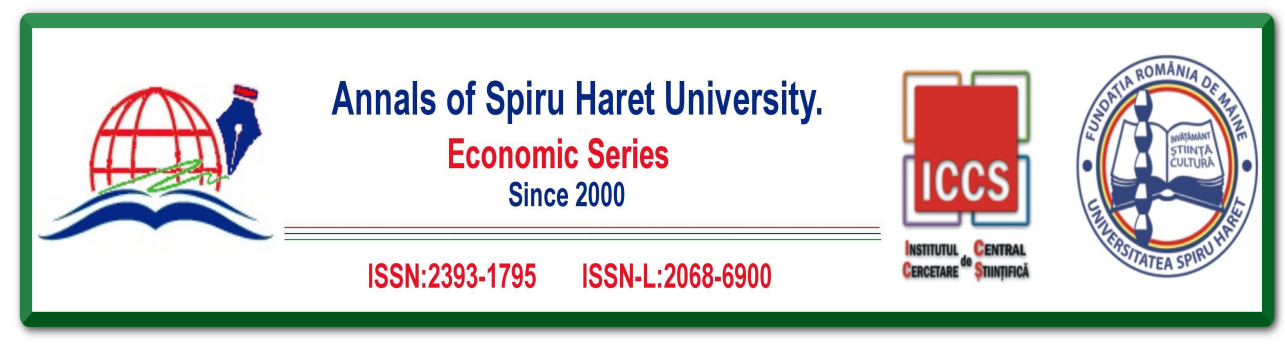

Issue 2/2019

protein from livestock and plants required for body building, availability of raw materials for industries, job creation and finance for more investments. Over the years, countries have treasured the contributions of agriculture, which is not dependent on oil and it is incessant and accessible by every household in a nation, because people willingly and joyfully cultivate, practice one form of agriculture or the other without being coaxed to do so. Agriculture is seen as a long lasting heritage which passes from generation to generation and the modern way in which it is being practiced has added more value and boost to it, as a result most countries find it as a means of sustaining their economy.

\subsection{Theoretical Framework}

The economic theory underpinning this study is the endogenous economic growth theory championed by Romer (1994). The theory holds that economic growth depends on investment in human capital, innovation and knowledge management. Endogenous economic growth theory also advocates all government efforts and policies geared towards promoting economic growth through all available and potential sources such as agriculture, taxation and development of natural resources. This study focuses on the contributions of oil revenue, non-oil tax revenue and agriculture to economic growth. It is necessary that the government makes policies that will promote the contributions of these key components of the Nigerian economy, especially agriculture. The policies should include more government investments in agriculture and creating of the enabling environment for foreign investors to see agribusiness in Nigeria as a viable area for investment. Government policies should equally incorporate fiscal policies that will enable tax administration in Nigeria to be well organized and business growth conscious. When it will be business growth conscious, the companies will no longer be allowed to fold because of inability to pay tax but rather, some form of incentives should be encouraged to keep companies in business. Endogenous economic growth theory is all encompassing and this is why it goes beyond the limitations of other economic growth theories.

\subsection{Empirical review}

\subsubsection{Studies on Oil Revenue and Economic Growth}

Akinlo (2012) used VAR model to assess the contribution of oil to economic growth in Nigeria from 1960 to 2009. The study assessed the influence of oil on five subsectors of the economy which include: building and construction, manufacturing, agriculture, trade and services. The findings revealed, among others, that oil had 


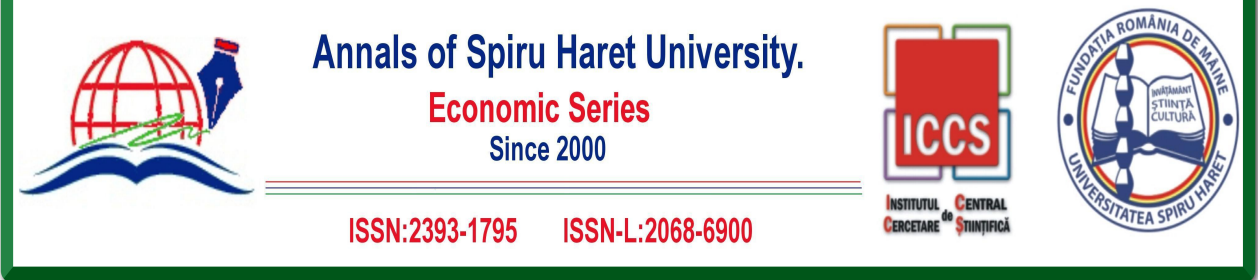

\section{Issue 2/2019}

negative impact on the manufacturing subsector. Baghebo and Atima (2012) used data covering a period from 1980 to 2011 to assess the impact of petroleum on economic growth in Nigeria. Thus, the study found the existence of a long run relationship between oil revenue and economic growth.

Ibeh (2013) employed ordinary least squares (OLS) method to investigate the effect of oil revenue on economic growth in Nigeria using annual time series data spanning from 1980 to 2010 . The findings revealed that oil revenue had significant effect on the economic growth of Nigeria. Adesola et al. (2014) examined the impact of oil revenue on economic development in Nigeria using data that spanned from 1981 to 2012. The result of the regression analysis revealed a very high relationship between oil revenue and economic development, thereby signifying over dependence of the country on oil revenue.

Abubakar et al. (2016) investigated the impact of oil revenue on the Nigerian economy using other economic sectors which comprise health, education, agriculture among others to assess the association between oil revenue and the economy. The study found evidence that oil revenue had an insignificant influence on the key economic sectors in Nigeria. Asagunla and Agbede (2018) used Fully Modified Ordinary Least Squares (FMOLS) method to assess the impact of oil revenue on economic growth in Nigeria from 1981 to 2014. The study found evidence that oil revenue did not have a short term influence on economic growth in Nigeria, while confirming that a continuous rise in oil revenue would definitely result to economic growth in the future.

\subsubsection{Studies on Non-Oil Tax Revenue and Economic Growth}

Stoilova and Patonov (2012) employed panel data of 27 European Union countries to investigate the impact of tax revenue on economic growth from 1995 to 2010. The findings revealed that direct tax revenue had a significant positive impact on economic growth of the EU countries. Otu and Adejuma (2013) examined the effects of tax revenue on economic growth in Nigeria using time series data that covered a period from 1970 to 2011. The study employed ordinary least squares regression method and the findings indicated that tax revenue had a positive and significant effect on economic growth in Nigeria.

Ayuba (2014) also adopted ordinary least squares regression technique to examine the impact of non-oil tax revenue on economic growth in Nigeria from 1993 to 2012. The findings indicated that non-oil tax revenue had a significant positive impact on economic growth in Nigeria. Lyndon and Paymaster (2016) made use of annual time 


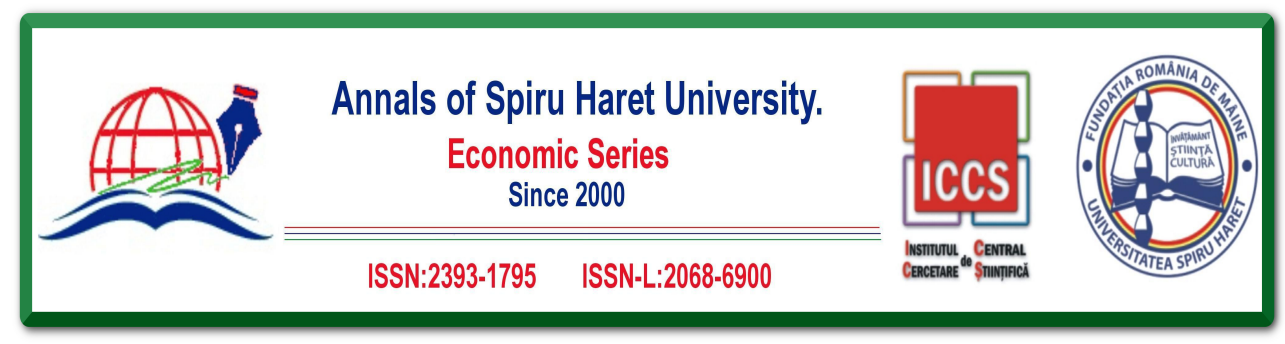

Issue 2/2019

series data which covered a period from 2005 to 2014 to assess the influence of value added tax (VAT) and companies' income tax (CIT) on economic growth in Nigeria. The findings revealed that both VAT and CIT significantly and positively impacted on Nigeria's economic growth. Popoola, Jimoh and Oladipo (2017) extended the study from 1986 to 2015 using both non-oil tax revenue and oil revenue; the study found evidence that non-oil tax revenue and oil revenue had significant and positive impact on economic growth of Nigeria.

\subsubsection{Studies on Agriculture and Economic Growth}

Eze (2017) assessed the contribution of agricultural sector to economic growth in Nigeria from 1980-2014 using vector error correction model and Granger causality test. The study revealed that agricultural output contributed to economic growth significantly and positively. Kamil et al. (2017) examined the contributions of agricultural sector on economic growth of Nigeria from 1981 to 2013 using vector error correction model. The result showed that agriculture had a positive impact on economic growth. Thus, the study encouraged diversification of the economy and more allocation to agricultural sector in the annual budget.

Oguwuike (2018) investigated the effect of agricultural output on economic growth in Nigeria by considering each component of agriculture and the specific contribution to GDP used as proxy for economic growth. The findings revealed that crop production, fishing and livestock contributed positively and significantly to GDP, while forestry had significant negative influence on GDP.

Omodero and Amah (2018) used ordinary least squares technique to evaluate the role of all aspects of agriculture in Nigeria which comprise crop production, fishery, forestry and livestock farming in reducing cost of living in the country. The study spanned from 1981 to 2017 and found evidence that crop production and livestock farming had a significant positive effect on cost of living. In other words, they played more role in reducing consumption cost. On the contrast, fishing and forestry had negative influence on cost of living, which implies that their contribution could not reduce cost of living in the country. The study suggested that all aspects of agriculture in the country should be given financial boost to actually impact on the economy positively and significantly.

This current study is a combination of the contributions of three major areas that sustain the economy of Nigeria, thus, they are being investigated to establish their respective impact on GDP. 


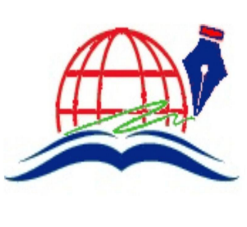

Annals of Spiru Haret University.

Economic Series

Since 2000
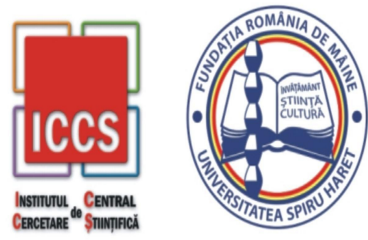

Issue 2/2019

\section{Methodology}

\subsection{Research Design}

This study made use of quasi-experimental design in order to realize its purposes. Here the research adopted the econometric analysis techniques of ordinary least squares (OLS) multiple regression technique. This research design is necessary because the selected research area for investigation is empirical, quantitative and analytical in nature, where as the response and explanatory variables are perceived over a time frame for any variation that can possibly occur.

\subsection{Types and Sources of Data Collection}

The study made use of secondary form of data because the research work is analytical in nature. Time series data relating to the dependent and explanatory variables used covered a period from 1981 to 2017. All the data employed in this study were obtained from the Central Bank of Nigeria Statistical Bulletin, 2017 edition.

\subsection{Model Specification}

The functional and econometric relationship between the dependent variable and the independent variables are seen in the equation below:

$\mathrm{GDP}=\mathrm{f}(\mathrm{ORV}, \mathrm{NRV}, \mathrm{AGR})$

$\mathrm{GDP}=\beta_{0}+\beta_{1} \mathrm{ORV}+\beta 2 \mathrm{NRV}+\beta 3 \mathrm{AGR}+\mu$

Where: GDP = Gross Domestic Product; ORV = Oil Revenue; NRV = Non-oil Revenue; AGR $=$ Agriculture; $\beta_{0}=$ Constant; $\beta_{1}-\beta_{3}=$ Regression coefficients; $\mu=$ Error term.

On the a priori, we expect; $\beta_{1}>0, \beta_{2}>0, \beta_{3}>0$.

\section{Data Analysis and Interpretations}

Table 1. Model Summary of results

\begin{tabular}{|c|c|c|c|c|c|}
\hline Model & $\mathrm{R}$ & R Square & $\begin{array}{l}\text { Adjusted R } \\
\text { Square }\end{array}$ & $\begin{array}{l}\text { Std. Error of } \\
\text { the Estimate }\end{array}$ & Durbin-Watson \\
\hline 1 & 0.990 & 0.980 & 0.978 & 5058.17847 & 1.286 \\
\hline
\end{tabular}

a. Predictors: (Constant), AGR, NRV, ORV

b. Dependent Variable: GDP

Source: Author's computation, 2019. 


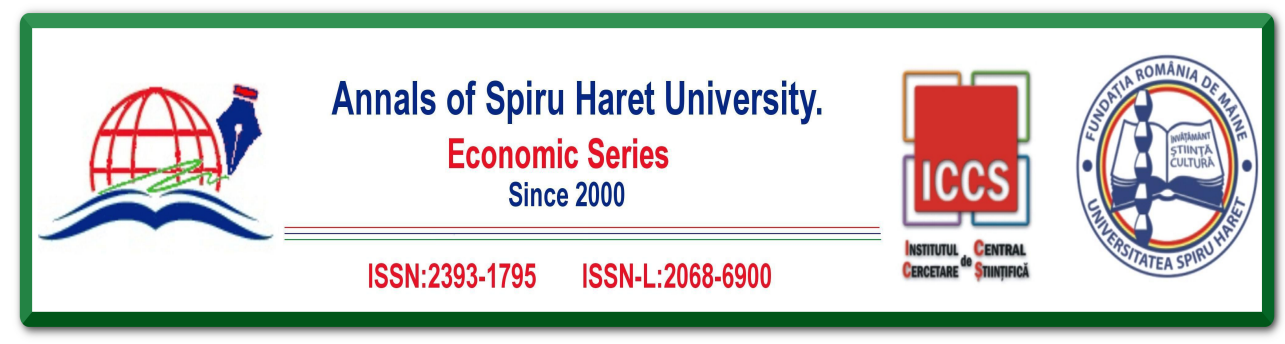

Issue 2/2019

From table 1 above, the $\mathrm{R}$ value which signifies the correlation is $99 \%$, showing a very strong relationship between economic expansion and the independent variables used in this study. This degree of association implies that the economic growth of Nigeria is heavily dependent on oil revenue, non-oil tax revenue and contributions from agricultural sector. The R Square is also another indicator showing the extent the predictor variables explain the changes in GDP. The value is $98 \%$, which implies that it is only the remaining $2 \%$ that can be associated with other economic factors that are not considered in this study. Thus, the independent variables determine up to $98 \%$ of the movements in GDP. The Durbin-Watson is within the limit that does not create room for concern, because it is above 1 and not above 3 .

Table 2. ANOVA

\begin{tabular}{|c|c|c|c|c|c|}
\hline Model & Sum of Squares & Df & Mean Square & $\mathrm{F}$ & Sig. \\
\hline Regression & 41530828816.687 & 3 & 13843609605.562 & 541.079 & $0.000 *$ \\
\hline Residual & 844310592.301 & 33 & 25585169.464 & & \\
\hline Total & 42375139408.988 & 36 & & & \\
\hline
\end{tabular}

a. Dependent Variable: GDP

b. Predictors: (Constant), AGR, NRV, ORV

$*$ = Significant at $1 \%$

Source: Author's computation, 2019.

Table 2 above shows that the value of F statistic is 541.079 and has the p-value of $0.000<0.05$. This value implies that the result is statistically significant and the model is a good fit for the study. The result also indicates that the predictor variables jointly influence the dependent variable positively and significantly.

\subsection{Test of Hypotheses}

Hol: Oil revenue does not have significant influence on economic expansion in Nigeria

The study earlier suggested that oil revenue does not have significant impact on economic growth in Nigeria. ORV t-statistic is -3.010 with the p-value of $0.00<$ 0.05 level of significance. This result shows that oil revenue has a significant negative impact on economic growth. Thus, the Hol which states that oil revenue does not have significant impact on economic expansion is hereby accepted and the 


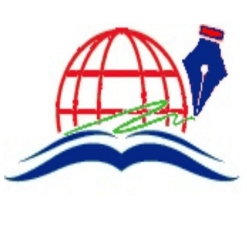

Annals of Spiru Haret University.

Economic Series

Since 2000
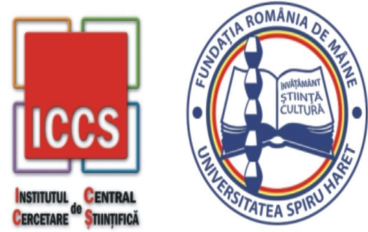

Issue 2/2019

alternative which suggests otherwise rejected. The result agrees with the findings of Akinlo (2012) and Abubakar et al. (2016), while conflicting with the findings of Adesola et al. (2014).

Table 3. Coefficients

\begin{tabular}{|c|c|c|c|c|c|}
\hline \multirow[t]{2}{*}{ Model } & \multicolumn{2}{|c|}{ Unstandardized Coefficients } & \multirow{2}{*}{$\begin{array}{c}\text { Standardized } \\
\text { Coefficients }\end{array}$} & \multirow[t]{2}{*}{$\mathrm{T}$} & \multirow[t]{2}{*}{ Sig. } \\
\hline & B & Std. Error & & & \\
\hline (Constant) & -460.175 & 1100.899 & & -0.418 & 0.679 \\
\hline ORV & -1.699 & 0.564 & -0.133 & -3.010 & $0.005 *$ \\
\hline NRV & 33.368 & 1.322 & 1.093 & 25.249 & $0.000 *$ \\
\hline AGR & 0.015 & 0.005 & 0.074 & 2.819 & $0.008 *$ \\
\hline
\end{tabular}

a. Dependent Variable: GDP

$*=$ Significant at $1 \%$

Source: Author's computation, 2019.

Ho2: Non-oil tax revenue does not significantly affect economic growth in Nigeria

The study initially postulated that non-oil tax revenue does not have significant impact on GDP. From the regression result on table 3 above, this claim has been refuted. NRV t-statistic is 25.249 , while the p-value is $0.000<0.05$ level of significance. This result shows that NRV has a robust significant positive impact on GDP, therefore, Ho2 is hereby rejected while the alternative suggestion is accepted. This result is in harmony with the empirical evidences from [Stoilova \& Patonov, 2012; Adejuma, 2013; Ayuba, 2014; Lyndon \& Paymaster, 2016; Popoola et al., 2017].

Ho3: Agriculture does not have significant impact on economic growth in Nigeria

The study firstly posited that revenue from agriculture does not affect GDP significantly. From table 3 above, AGR t-statistic is 2.819 and the p-value is $0.00<$ $0.05 \%$ level of significance. This result implies that agriculture is contributing positively and significantly to GDP. Thus, Ho3 is annulled while the alternative which states otherwise is established. This result is in agreement with the findings of Eze (2017) and Kamil et al. (2017) among others. 


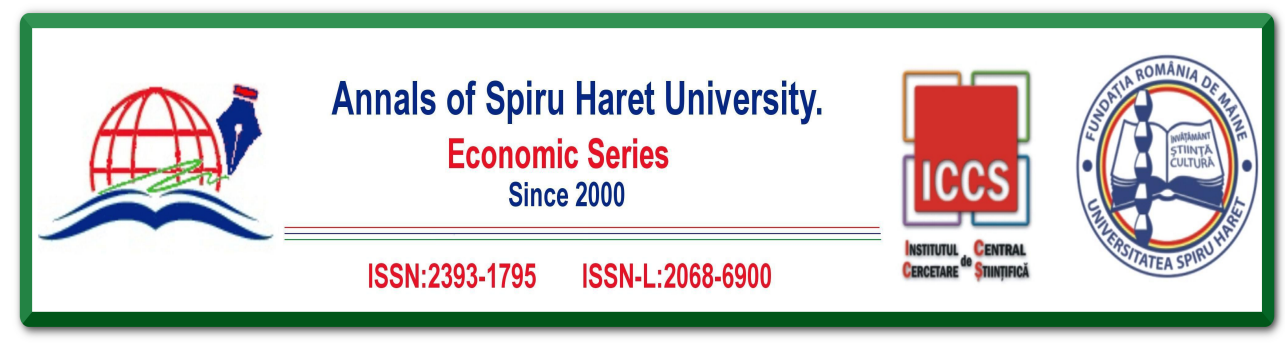

Issue 2/2019

\section{Conclusion and Recommendations}

\subsection{Conclusion}

The study considered the impact of revenues accruing from oil, non-oil tax revenue and agriculture on economic growth in Nigeria. The economic a priori expectation is that oil revenue, non-oil tax revenue and revenue from agriculture should be greater than zero which signifies that they should contribute positively to economic growth in the country. The regression results have shown that non-oil tax revenue and agriculture met this expectation while oil revenue fell below expectation. The study therefore concludes that Nigeria's over reliance on oil is an error because the contribution to economic growth is reducing due to dwindling oil prices, mismanagement of resources, political and ethnic conflicts, corruption and huge government expenditures.

\subsection{Recommendations}

- The study recommends economic diversification into agriculture and other areas which is now necessary for economic growth in the country. Foreign investment in all components of agriculture in Nigeria should be encouraged by creating the enabling environment that will attract foreign investors into the sector.

- Taxation has been proved as a potential means of keeping the general economy growing, thus, its administration should be improved in order to eradicate tax evasions. Tax administration and fiscal policies should be business-growth conscious among others. If tax is well administered and the revenue well utilized, evasions will hardly occur because tax payers will be happy fulfilling their civic responsibilities knowing fully well that it is used for provision of public goods and services.

- Finally, over dependence on oil revenue should be curtailed while all oil revenues accruing from sale of crude oil, petroleum profit tax and other oil revenue sources should be utilized to improve the country, through reinvestments into other sectors of the economy.

\section{References}

[1] Abubakar, A.A. (2011). Political participation and discourse in social media during the 2011 Presidential Electioneering. Paper presented at the ACCE, Covenant University, Ota. September 2011. 


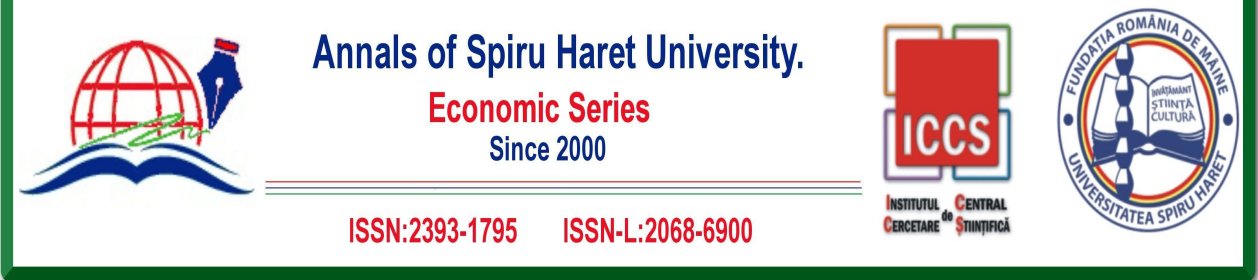

\section{Issue 2/2019}

[2] Abubakar, M. Y., Ahmad, S. S., Sani, S. B., \& Jinjiri, A. Y. (2016). "Analysis of the impact of oil Revenue on the Nigerian economy." IOSR Journal of Economics and Finance, 7(4), 10-21.

[3] Adesola, O. A., Adesodun, A. I., \& Adekola, D. R. (2014). "Impact of oil revenue on economic Development in Nigeria (1981-2012)." Journal of Social and Development Sciences, 5(2), 73-78.

[4] Akanbi, O., \& Du Toit, C. B. (2011). "Macro-econometric modelling for the Nigerian Economy: A Growth poverty gap analysis." Journal Economic Modelling, 28, 335-350.

[5] Akinlo, A. E. (2012). "How important is oil in Nigeria's economic growth?" Journal of Sustainable Development, 5(4), 165-179. DOI: 10.5539/jsd.v5n4p165.

[6] Asagunla, T. M., \& Agbede, M. O. (2018). "Oil revenue and output growth in Nigeria." IIARD International Journal of Economics and Business Management, 4(6), 65-74.

[7] Ayuba, A. J. (2014). "Impact of non-oil tax revenue on economic growth: The Nigerian perspective." International Journal of Finance and Accounting, 3(5), 303-309. DOI: 10.5923/j.ijfa.20140305.04.

[8] Beghebo, M. \& Atima T. O. (2013). "The impact of petroleum on economic growth of Nigeria." Global Business and Economic Journal.

[9] Fafunwa, A. B. (2005). "Collapse in Educational System: Our Collective Failure." The Guardian News. Retrieved from: www.guardiannews.ng.com on March 20, 2019.

[10]Hammond, J. L. (2011). "The Resource Curse and Oil Revenues in Angola and Venezuela." Journal of Science and Society, Vol. 75, No. 3, pp. 348-378.

[11] Ihendinihu, J. U., Ebieri, J., \& Ibanichuka, A. E. (2014). "Assessment of the long-run equilibrium Relationship between tax revenue and economic growth in Nigeria, 19862012." The SIJ Transactions on Industrial, Financial \& Business Management (IFBM), 2(2), March-April.

[12] Ibeh, F. U. (2013). The Impact of Oil Revenues on the Economic Growth in Nigeria. Caristas University.

[13] Lambo, E. (2005). "Minister Decries State of Health System." The Guardian News. Retrieved from: www.guardiannews.ng.com on March 20, 2019.

[14] Lyndon, M. E. \& Paymaster, F. B. (2016). "The Impact of Company Income Tax and Value added Tax on Economic Growth: Evidence from Nigeria." European Journal of accounting, auditing and finance research 4(7), 106-112.

[15]Nightingale, K. (1997). Taxation Theory and Practice. United Kingdom. Pitman Press.

[16] Obaji, C. (2005). Nigeria Cannot Justify N40 Billion Spent on Education. The Punch News. Retrieved from www.punch.ng.com on March 20, 2019.

[17] Ogundele, A. E. (1999). Elements of Taxation. 1st Edition, Lagos Libri Service.

[18] Okafor, R. G. (2012). "Tax revenue generation and Nigerian economic development." European Journal of Business and Management, 4(19), 49-56. 

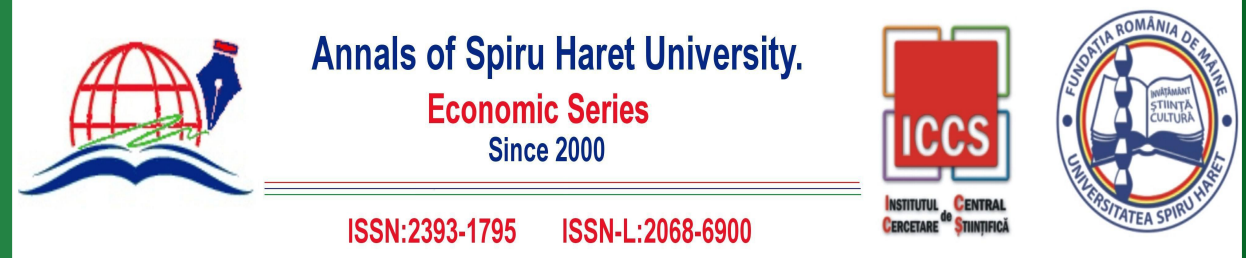

Issue 2/2019

[19] Owolabi, A. \& Ajayi, N. O. (2013). "Econometrics analysis of impact of capital market on Economic growth in Nigeria (1971-2010)." Asian Economic and Financial Review, $3(1), 99-110$.

[20] Otu, H. B. \& Adejumo, T. O. (2013). "The effects of tax revenue on economic growth in Nigeria (1970-2011)." International Journal of Humanities and Social Science Invention, 2(6), 16-26.

[21] Popoola, A. A., Jimoh, I. \& Oladipo, A. A. (2017). "Tax revenue and Nigerian economic growth." European Journal of Accounting, Auditing and Finance Research, 5(11), 75-85.

[22] Sanni, A. (2005). Contentious issues in Tax Administration and Policy in Nigeria: A State Governors Perspective. Paper Presentation by Executive Governor of Zamfara State at the 1st National Retreat on Taxation.

[23] Soyode, L. \& Kajola, S. O. (2006). Tax: Principles and Practice in Nigeria. 1st Edition: Ibadan, Silicon.

[24] Stoilova, D. \& Patonov, N. (2012). "An empirical evidence for the impact of taxation on economic Growth in the European Union." Book of Proceedings - Tourism and Management Studies International Conference, Portugal, Algarve, Vol. 3, 1031-1039. 
